\title{
Letter from the Editor
}

The three dozen special issues and symposia that have appeared in Central European History (CEH) over the past five decades have all been dedicated to either specific historical themes or novel historiographical approaches. The first, which appeared in the winter of 1971 to mark the hundredth anniversary of German unification, was simply titled "1870/71," and its five articles suggested the journal's strong concentration at the time on political, diplomatic, and military history. The next two-symposia on "Government, Social Structure, and Cultural Life in Germany" (June 1978) and "International Migration" (December 1980)—reflected the field's subsequent turn toward social history. Thematic issues have been most common, and the usual suspects- the Weimar Republic, the Third Reich, and the post-1945 period-have all received their fair share of attention. ${ }^{1}$ The Holy Roman Empire, the French Revolution and the Napoleonic period, as well as the Kaiserreich have been the subjects of special issues as well, ${ }^{2}$ and religion and religious practices have also been popular. ${ }^{3} \mathrm{~A}$ handful of issues has either assessed old historiographical controversies and the impact of influential studies (e.g., the Fritz Fischer controversy and Mack Walker's German Home Towns), or served as the venue for carrying out new debates, such as the one surrounding the contentious research practices of David Abraham. ${ }^{4}$ Finally, a smaller number of special issues has focused on new historiographical approaches and methods: "German Histories: Challenges in Theory, Practice, Technique" (September/December 1988), for example, looked in particular at the promising vistas offered by the "new cultural history" and the so-called linguistic turn.

The present special issue of CEH belongs to this last category and is dedicated to another "turn": the visual or pictorial. Assembled and introduced by guest editors Elizabeth Harvey and Maiken Umbach, the five articles that make up "Photography and Twentieth-Century German History" cover a broad time span - the Kaiserreich, the Weimar Republic, the Third Reich and the Holocaust, as well as the German Democratic Republic - and a wide range of themes, from the Lodz Ghetto to the gay scene in East Germany, from the working classes to the GermanJewish middle class. The authors examine a variety of photographs - from staged scenes to seemingly casual snapshots - in order to illustrate the many challenges involved in using photographs as historical sources. As Harvey and Umbach point out in their Introduction, the various analyses warn us against certain pitfalls when it comes to the use of photographs and other visual evidence-simply employing them, for instance, in a methodologically unsophisticated way as

\footnotetext{
1 "New Perspectives on the German Resistance against National Socialism” (December 1981); "Who Voted for Hitler?" (March 1984); "Hindenburg and the Weimar Republic" (June/Sept. 1990); "Continuity and Change in Germany after 1945" (June 1985); "Post-World War II Germanies" (March 1993); “The GDR as Historical Subject" (Sept. 1995); "Women and the Welfare State in the Weimar Republic" (March 1997); "The Holocaust and Modernity" (Sept. 1997); "Unexplored Aspects of Nazi Germany" (March 1999); "From the Archives of the Former GDR" (June 1999); "Germans as Victims during the Second World War" (March 2005); "Culture of Politics-Politics of Culture: New Perspectives on the Weimar Republic" (Dec. 2010); "New Perspectives on the Nazi Storm Troopers" (June 2013).

2"The Culture of the Holy Roman Empire, 1540-1680" (March 1985); "The French Revolution in Germany and Austria” (June 1989); “W. E. B. Du Bois and the Kaiserreich" (Sept. 1998); "Collaboration, Resistance, and Reform: Experiences and Historiographies of the Napoleonic Wars in Central Europe" (Dec. 2006).

3"Catholics and Politics in Nineteenth-Century Germany" (March 1986); "Reformation and Revolution: From the Sacral Community to the Common Man" (Sept./Dec. 1987); "Christian Religion and Anti-Semitism in Modern German History" (Sept. 1994); "Priests and Pastors in Central Europe 1500-1700" (March 2000).

4 "Debate: David Abraham's The Collapse of the Weimar Republic" (June/Sept. 1984); "The German Empire and the First World War: A Quarter Century after the Fischer Controversy" (Sept. 1988); “The Peasantry in Early Modern Central Europe: The State of the Field" (Sept. 2001); "Forum: German Home Towns, Forty Years Later" (Sept. 2014).
} 
mere "illustrations" or "supplementary" evidence for what we already "know" from the written record. This prompts an important question: What new insights, if any, do photographs provide? In other words, what might they "say in a thousand words" that a more traditional type of document does not?

At the same time, the articles explore, and ask us to think about, a different relationship between visual and written "texts": namely, the fact that both types can be "read" in myriad ways and in a manner much different from the one(s) intended by those who fashioned them-something that Socrates already alerted us to almost two and a half centuries ago in Plato's Apologia, when he craftily suggested that his interpretations of poems and prophecies were just as "valid" as those of their creators. In a similar vein, the various "meanings" of photographs evolve over time as well, sometimes taking on new ones vastly different from what the photographers themselves (may have) originally intended. All of this reminds us of a related but essential point: that photographs are not somehow more "objective" or "authentic" historical sources because of their seeming immediacy and spontaneity. Like all other types of document, they are embedded in - and need to be interpreted within - given political, cultural, and socio-economic contexts; that is to say, they are part of a larger discursive and visual milieu to which they not only refer but which they also help create. Photographs have multiple meanings, in short, and the greatest challenge to the historian is deciphering those meanings.

But what constitutes a "persuasive" interpretation, and are some interpretations more persuasive than others? Like the three anonymous readers who kindly agreed to provide feedback on these articles-and upon whose insights I rely in this Letter-not all readers of this issue will be persuaded by all the authors' arguments and interpretations. Some will find them highly speculative, in fact. But that, like much of the "new cultural history," is the nature of the beast. Those of us with postmodernist sensibilities may accept the idea that there is no single "truth" or privileged perspective from which one may interpret material or pass judgment. Still, most of us would consider some analyses to be better supported than others-even if such judgments are themselves, in turn, equally subjective. Each reader of this special issue will have to be his or her own final arbiter on that score.

Such considerations notwithstanding, the articles as a whole usefully remind us how imperative it is to approach visual evidence in the same critical way as any other source: by reading them "against the grain" and with an eye to shifting contexts and meanings. As Harvey and Umbach rightfully insist, stringent Quellenkritik is especially important with respect to photographs and photographic practices - not least because of the determinative role they have played in not only recording but also shaping modern history and historical memory.

ANDREW I. PorT EDITOR 